FUNERARY PRACTICES IN

THE CZECH REPUBLIC 


\title{
Funerary International
}

\author{
Series Editor: Julie Rugg, University of York, UK
}

The study of mortality is now an established academic endeavour which is rapidly expanding in scale and in disciplinary reach. One missing element is a repository of basic facts about funerary practice in each country and the broader legal, governance and denominational frameworks for those practices which might serve to set more detailed research in context.

This book series remedies this absence by producing countryspecific monographs, with texts providing a standard framework of questions, which ensures even coverage; aids international comparison; fosters international linkages across the academic community; and inspires new research directions. These texts will be a valuable resource for researchers across the humanities and social sciences concerned with death and funerary customs.

Previous titles in this series

Julie Rugg and Brian Parsons, Funerary Practices in England and Wales

Brenda Mathijssen and Claudia Venhorst, Funerary Practices in the Netherlands

Forthcoming in this series

Maija Butters and Ilona Pajari, Funerary Practices in Finland

Sergei Mokhov, Funerary Practices in Russia

Aleksandra Pavićević, Funerary Practices in Serbia

José Francisco Ferreira Queiroz, Ana Rafaela Ferraz Ferreir and Ana Júlia Almeida Miranda, Funerary Practices in Portugal

Christoph Streb, Funerary Practices in Germany 


\title{
FUNERARY PRACTICES IN THE CZECH REPUBLIC
}

\author{
OLGA NEŠPOROVÁ \\ Institute of Ethnology of the Czech \\ Academy of Sciences, Czech Republic
}

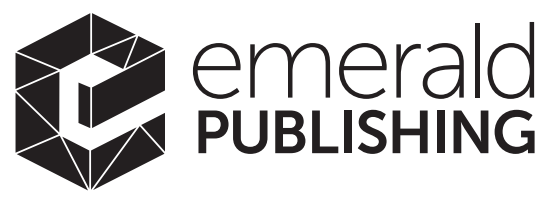

United Kingdom - North America - Japan - India Malaysia - China 
Emerald Publishing Limited

Howard House, Wagon Lane, Bingley BD16 1WA, UK

First edition 2021

(C) 2021 Olga Nešporová. Published under exclusive licence by Emerald Publishing Limited.

\section{Reprints and permissions service \\ Contact: permissions@emeraldinsight.com}

No part of this book may be reproduced, stored in a retrieval system, transmitted in any form or by any means electronic, mechanical, photocopying, recording or otherwise without either the prior written permission of the publisher or a licence permitting restricted copying issued in the UK by The Copyright Licensing Agency and in the USA by The Copyright Clearance Center. Any opinions expressed in the chapters are those of the authors. Whilst Emerald makes every effort to ensure the quality and accuracy of its content, Emerald makes no representation implied or otherwise, as to the chapters' suitability and application and disclaims any warranties, express or implied, to their use.

British Library Cataloguing in Publication Data

A catalogue record for this book is available from the British Library

ISBN: 978-1-78973-112-5 (Print)

ISBN: 978-1-78973-109-5 (Online)

ISBN: 978-1-78973-111-8 (Epub)

ISOQAR certified

Management System,

awarded to Emerald

for adherence to

Environmental

standard

ISOQAR

ISO 14001:2004.

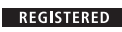

Certificate Number 1985

ISO 14001

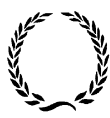

INVESTOR IN PEOPLE 


\section{TABLE OF CONTENTS}

List of Figures ix

List of Tables $\quad$ xi

List of Abbreviations xiii

Foreword $\quad x V$

Acknowledgements xix

Map of the Czech Republic xxi

1. Introduction 1

2. History 5

2.1 The Eighteenth, Nineteenth and Twentieth Centuries $\quad 5$

2.1.1 Demography and Epidemiology 7

2.1.2 Burial Sites 10

2.1.3 The Funeral Directing Industry 14

2.2 The Cremation Movement 15

2.2.1 The Czech German Cremation Movement 16

2.2.2 The Czech Cremation Movement 18

2.2.3 The Interwar Period 21

2.3 The First and Second World Wars 24

2.3.1 The First World War 24

2.3.2 Influenza Pandemic 25

2.3.3 The Second World War 26

2.4 The Communist Period in Czechoslovakia (1948-1989) 27 
2.4.1 The Promotion of Civil Funerals 30

2.4.2 Infrastructure $\quad 30$

2.4.3 The Occurrence of Secular Funerals $\quad 32$

2.5 Following the Velvet Revolution in $1989 \quad 34$

2.5.1 Continuity in the Funeral Industry 35

2.5.2 Religion and Secularisation 36

3. Demographic and Legal Frameworks 39

3.1 The Demography of Mortality 39

3.2 Czech Legislation Concerning Death 43

3.2.1 The Registration of Deaths 43

3.2.2 Social Funerals 46

3.3 Principal Legislation Concerning Funeral Directing 47

3.3.1 Trade Licence 48

3.3.2 Advertising Regulations 49

3.3.3 The Regulation of Funeral Fees 49

3.3.4 Planning and the Environment 51

4. Crematoria and Cremation 53

4.1 Development since the 1950s 53

4.1.1 The Period of Communist Rule

(1948-1989) 53

4.1.2 The Post-communist Period (after 1989) 58

4.2 Cremation Rates since the 1950s 59

4.3 The Functioning of Crematoria 61

4.3.1 Running a Crematorium 63

4.3.2 The Cremation Industry 64

4.3.3 The Cremation Process 65

4.4 The Disposal of the Ashes 66

4.4. 1 Placing the Ashes in a Grave or

Columbarium 68

4.4.2 The Scattering of the Ashes 70

4.4.3 The Digging in of the Ashes under a

Piece of Lawn 
5. The Funeral and the Funeral Ceremony

5.2 The Typical Funeral: Secular Funeral with a Civil Ceremony

5.2.1 The Time between Death and the Funeral

5.2.2 Ordering a Funeral

5.2.3 The Death Notice

5.2.4 The Funeral Ceremony

5.2.5 Dress Code

91

5.2.6 Funeral Tea

91

5.2.7 General Facts about Secular Funeral Ceremonies

5.3 The Religious Funeral - Roman Catholic 94 5.3.1 Religious Affiliation

5.4 Cremation without a Funeral Ceremony

5.5 DIY Funerals

6. Funeral Costs

105

6. 1 The Costs of Funeral Services

6.1.1 Minimum and Average Prices

6.1.2 Direct Cremation

6.1.3 Social Funerals

6.1.4 The Funeral Grant

6.2 Cemetery Costs

7. Burial Sites

7.1 Burial Sites in History

7.2 Statistics on Contemporary Burial Sites

7.3 War Graves and Memorials

7.4 Burial Sites

7.4.2 Dedicated Areas for the Placing of the Ashes 
7.4.3 Graves

7.4.4 The Lease of Graves 126

7.4.5 Legislation 127

7.4.6 Conservation and the Funerary

Heritage

7.4.7 Well-known Cemeteries

7.5 Natural Burial

8. Commemoration

8.1 The Visiting of Cemeteries

133

8.2 Roadside Memorials

8.3 Virtual Commemoration

Bibliography

Index 


\section{LIST OF FIGURES}

Figure 2.1. The First Crematorium in the AustroHungarian Empire in Liberec.

Figure 2.2. The Pardubice Crematorium Constructed in the Czech National Rondo-Cubism Style.

Figure 2.3. Monumental Crematorium in Prague Strašnice, Opened in 1932.

Figure 2.4. A Secular Funeral Hall in Jičín.

Figure 4.1. The Development of the Crematoria Network in the Former Czechoslovakia.

Figure 4.2. The Crematorium in Zlín.

Figure 4.3. The Crematorium in Kladno.

Figure 4.4. A Cemetery Wall: Columbaria Niches with Glass Doors.

Figure 4.5. Digging in of the Ashes under a Piece of Lawn.

Figure 4.6. Small Homemade Ulrn Grave in a Garden.

Figure 5.1. Charts Displaying the Proportions of the Main Types of Funerals in Different Parts of the Czech Republic: Percentages. 
Figure 5.2. Own Funeral Preferences According to Age: Percentages. 82

Figure 5.3. Death Notices on the Notice Board. 86

Figure 5.4. Coffin Resting on a Catafalque during Funeral Ceremony. 88

Figure 5.5. Funeral Procession Leaving the Church. 97

Figure 5.6. Lowering the Coffin into the Grave during a Religious Funeral. 98

Figure 7.1. Lawn for the Digging in of the Ashes at a Cemetery in Litomyšl.

Figure 7.2. Technical Scheme of a Grave.

Figure 7.3. Graves with Headstones with a Space for Urns.

Figure 8.1. Cemetery in Autumn on the Occasion of All Saints and All Souls Days.

Figure 8.2. Roadside Memorial Commemorating a Traffic Accident Victim. 


\section{LIST OF TABLES}

Table 2.1. Average Life Expectancy at Birth by Gender From 1875 to 1980.

Table 2.2. Cremations in the Czech Lands in the First Half of the Twentieth Century.

Table 2.3. Religious Affiliation in the Czech Lands According to Census Data 1921-201 1 :

Percentages.

Table 3.1. Development of Mortality Indicators in the Czech Republic (1980-2017).

Table 3.2. Place of Death in 2017: Percentages.

Table 4.1. Cremations in the Former

Czechoslovakia and Today's Czech

Republic in Selected Years

(1950-2018).

Table 5.1. Declared Church Affiliation and Religious Faith in the Czech Republic.

Table 6.1. Funeral Costs, 2016.

Table 6.2. Prices for Cemetery Services and

Equipment, 2016. 
This page intentionally left blank 


\section{LIST OF ABBREVIATIONS}

DIY Do it yourself

GDPR General Data Protection Regulation (EU) 2016/679

Čsú Český statistický úrad [Czech Statistical Office]

ÚZIS Ústav zdravotnických informací a statistiky ČR [Institute of Health Information and Statistics of the Czech Republic]

WHO World Health Organisation 
This page intentionally left blank 


\section{FOREWORD}

Even though the Czech Republic is only a small landlocked country situated in the middle of Europe, it is well known due to its rich history and numerous interesting historical sites, its beer and high number of successful sports players. It is also famous for having one of the lowest levels of religiosity in the world. Moreover, the country is also outstanding in terms of its funerary culture which is characterised by one of the highest cremation rates in Europe, a high proportion of secular funerals and a significant proportion of cremations with no funeral ceremony. The current situation in this respect is very much a legacy of the country's historical and cultural development, stemming particularly from practices introduced in the first half of the twentieth century that were purposely reinforced during the Communist era in the second half of the century.

As a social anthropologist, the author is naturally most concerned with the current situation with respect to funerary practices; however, she is well aware that no satisfactory account can be provided of the situation today without considering the historical background. Thus, the first chapter is devoted to the major developments that affected the funeral industry during the twentieth century, the most important of which were the advent of the cremation movement, the nationalisation of the funeral industry following the onset of 
the Communist era and the growing popularity of cremation without a ceremony.

As one long time participant in the funeral industry (born in 1925) commented in 2018 when asked whether she had witnessed any particularly abrupt changes in funeral practices during her lifetime:

'Those Communists eradicated religion.... This I see as the worst thing about the Communist era; not even during German rule [the Second World War Protectorate of Bohemia and Moravia] did this happen - funerals were conducted as normal. They [the Communists] just wanted [funerals to be held] without priests. They promoted that cremation idea!'1

The book then moves on to provide information on the current funerary cultural context including relevant legislation, cremation, the most common form of funeral, funeral costs, burial sites and commemoration. All the most important topics are covered in an attempt to provide the reader with similar information as that provided by the other books in this series, bearing in mind that the structure and the emphasis of the various chapters necessarily differ from country to country.

The author's interpretation of the current Czech funerary situation based on historical as well as contemporary research is that the historical legacy is of key importance. This legacy concerns both the various institutions and practices that have been established and their perception by ordinary Czech citizens. One of the most important factors here consists of the negative reactions of many as a result of the mandatory nature of many funerary practices introduced during the Communist era. To date, the import of funerary practices from abroad has been of minor significance due mainly to the very low level of

1 Face-to-face interview with a funeral professional from central Bohemia, 18 May 2018. The author's own field research. 
immigration to the Czech Republic; however, it is only reasonable to expect that the situation will change in this respect in the short to medium term. The current state of the Czech funerary culture is a mixture of approaches with the involvement of both the state and the private sectors; moreover, religion occupies an almost insignificant position and new secular practices are emerging only very gradually.

Olga Nešporová 
This page intentionally left blank 


\section{ACKNOWLEDGEMENTS}

I would like to acknowledge the funding received for the writing of this book via a research grant provided by the Czech Science Foundation (GAČR) as part of the Changes in funerary rites in Bohemia and Moravia during the twentieth century research project; reg. no. 19-09208S. The project is being conducted by researchers from the Institute of Ethnology of the Czech Academy of Sciences, Prague.

I would like to thank Julie Rugg, the editor of the Funerary International Series, for inviting me to write this book; on the one hand, she provided me with guidance and advice on what should be included in the book and, on the other, she allowed me both the freedom to emphasise what I considered important and to apply an approach that reflected my research specialisations and experience in this field. I would also like to gratefully acknowledge the understanding attitude of Philippa Grand while planning the schedule for my work on the book with respect to my other research project commitments. All those involved at Emerald Publishing Limited, especially Sophie Darling and Paula Kennedy, have been extremely helpful and supportive, for which I also express my grateful thanks.

If I consider the research that I have conducted in the field of death studies over the last 20 years or so, it is impossible to individually name all those who have provided assistance and support. Therefore, I will mention just a few of those persons and institutions with whom I have been privileged to work over the last two years of writing this book: Václav Graf, Adam 
Hájek, Zdeněk Lechner and David Ruman from TABO-CS spol. s r.o., Julius Mlčoch, Stanislav Motyčka from the Society of Friends of Cremation, Jiří Rak, Katarína Sabová from the Bratislava crematorium, Hana Svěchotová and the Czech Association of Funeral Directors. I am also indebted to numerous other funeral professionals who provided me with interviews and information as well as to ordinary people and academics who shared their thoughts on death, dying and disposal.

I would also like to express my gratitude to Hynek Dřevěný, Jakub Dvořák, Milan Mašek, Věnceslava Pícková and Pospíchal pohřební služba for enriching the visual content of the book by providing photographs and to Darren Ireland for the language corrections. The book includes photographs taken during the conducting of fieldwork concerning my previous research projects at the Charles University and the Institute of Ethnology of the Czech Academy of Sciences. Last but not least, I would like to thank my husband Zdeněk R. Nešpor who not only provided me with patient support while I was working on the manuscript, but also for reading the text and providing me with extremely useful feedback. I particularly acknowledge his input as a historian and specialist on the cremation movement. Of course, I personally accept full responsibility for all the information and interpretations presented in the book. 


\section{MAP OF THE CZECH REPUBLIC}

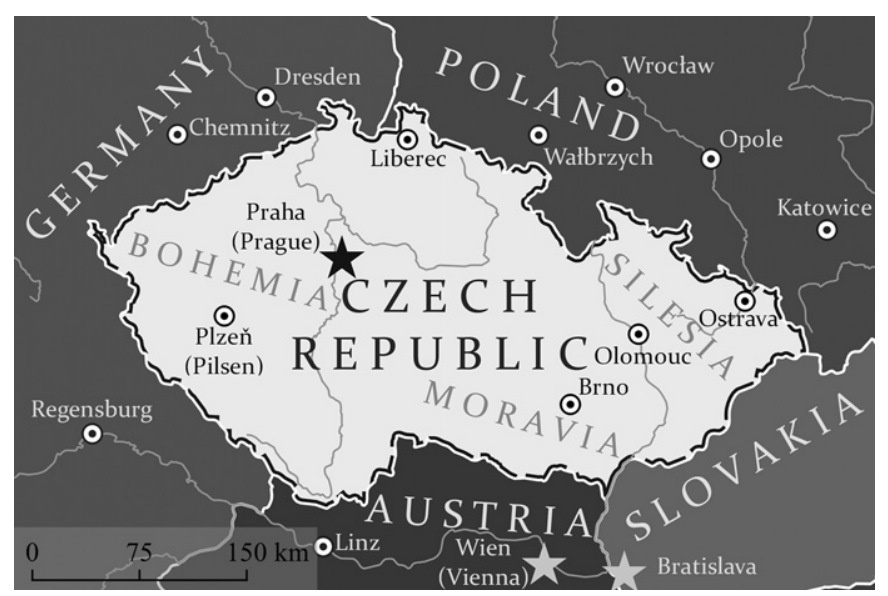

